\title{
LUT
}

University

Performance measurement approach for innovation capability in SMEs

Saunila Minna

This is a Post-print version of a publication

published by Emerald Group Publishing Limited

in International Journal of Productivity and Performance Management

DOI: $\quad$ 10.1108/IJPPM-08-2014-0123

Copyright of the original publication: (c) 2016 Emerald Group Publishing Limited

Please cite the publication as follows:

Saunila, M. (2016). Performance measurement approach for innovation capability in SMEs. International Journal of Productivity and Performance Management, vol. 65, issue 2. pp. 162-176. DOI: 10.1108/IJPPM-08-2014-0123

This is a parallel published version of an original publication. This version can differ from the original published article. 


\section{PERFORMANCE MEASUREMENT APPROACH FOR INNOVATION CAPABILITY IN SMES}

Purpose - The purpose of this paper is to present a framework for improving innovation capability through performance measurement in small- and medium-sized enterprises (SMEs). The development of an organisation's innovation capability is considered increasingly important in the current literature. Developing such capability is essential, as innovation plays a key role in the survival and growth of organisations. A review of current literature highlights the need for a framework on the development of innovation capability, especially in SMEs.

Design/methodology/approach - A literature review was used to form an understanding of previous work in the research area. Previous literature was used to define the key concepts and further to build the conceptual framework.

Findings - As a result of the study, a framework for improving innovation capability through performance measurement in SMEs is presented. Key issues that must be addressed are highlighted and discussed.

Practical/implications - The paper contains suggestions for improving innovation capability through performance measurement. Using the results of this study, practitioners can enhance their innovation capability by measurement and by taking better account of different situations regarding the development of innovation capability. The framework clarifies the issue of how innovation capability and its determinants can be managed through measurement, and therefore it assists especially SMEs in their attempts to cope with the increasing need for innovation as an asset of their business performance.

Originality/value - There are very few examples in the current literature of frameworks for the issue, especially for SMEs. The role of performance measurement in developing innovation capability is also ignored in the current literature. The paper is relevant for academics, as it clarifies the existing body of knowledge and provides a platform for future research.

Keywords: Performance, Innovation, SME, Performance measurement, Innovation capability

Publisher: Emerald Group Publishing Limited 


\section{Introduction}

The capacity to innovate has been suggested to be a key driver of a firm's success (Francis and Bessant, 2005; Kallio et al., 2012). The innovation capability of the firm depends for example on the knowledge that it possesses, as well as on its ability to deploy it (Delgado-Verde et al., 2011). The literature on innovation management contains frameworks examining the different areas of innovation capability (e.g. Lawson and Samson, 2001). These frameworks are on a very general level. In addition, the majority of studies have focused on innovation in larger companies (Forsman, 2011). However, small and medium sized enterprises (SMEs) may have distinct characteristics that differentiate them for larger companies. SMEs differ from larger companies by personalised management with little devolution of authority. They have resource limitations in terms of management and manpower as well as finance, and are usually dependent on a small number of customers and operating in limited markets. On the other hand, they also may have flat and flexible structures, high innovatory potential, reactive mentality, and informal, dynamic strategies (Hudson et al., 2001). Thus, it is unclear whether theories developed to understand large firms apply to SMEs (Hausman, 2005).

Innovation capability is actually one of the most important dynamics that enables SMEs to achieve a high level of competitiveness both in the national and international market. Thus, promoting and sustaining an improved innovation capability should be the key focus area of the top managers of SMEs (Çakar and Ertürk, 2010). The current approaches and frameworks do not give practical instructions on how especially SMEs can develop their innovation capability. There have also been few attempts of using a performance measurement approach to generate a framework of the development of innovation capability within SMEs. The current state of knowledge with respect to performance management and measurement in SMEs seems to be also limited to the study of SMEs from more traditional performance measurement perspectives (Bititci et al., 2012). Previous research has also shown that innovation capability can be facilitated through measurement (Saunila and Ukko, 2013). The measurement of innovation capability is rare in SMEs (Saunila et al., 2012). However, SMEs could benefit from performance measurement when improving their innovation capability. Performance measurement is today seen as a comprehensive process, which means that all things happening in the organisation are considered to have an impact on the performance of the organisation. These things include leadership and management, employees' task motivation, the quality of operations, and the ability of products to fulfil customers' needs (Franco and Bourne, 2003; Laitinen, 2003; Bourne et al., 2005; Ukko et al., 2008). The measures should be dynamic and changeable, supporting development and closure (Neely et al., 2000). Thus, measurement is not contradictory within the process of innovation, but can rather be used as a tool for developing innovation capability.

The purpose of this paper is to present a framework for improving innovation capability through performance measurement in SMEs. There are three key objectives to support the 
purpose: (1) defining innovation capability and its determinants; (2) identifying the uses and impacts of performance measurement especially when developing innovation capability; and (3) developing a conceptual framework to assist SMEs in their attempts to develop their innovation capability through measurement. Completing these objectives will help address the key research question that guides the paper: "What is the role of performance measurement in improving innovation capability in SMEs?" The framework presented is therefore aimed at highlighting the role of measurement when developing innovation capability and achieving higher performance.

The paper is organised into three sections. First, a review of literature that focuses on defining the key concepts, clarifying the uses and impacts of performance measurement, and the relationship between innovations and firm's performance is provided. The next section introduces a conceptual framework for developing innovation capability through performance measurement. The paper concludes with a discussion of the implications of the work and recommendations for further research.

\section{Literature review}

\section{1}

\section{Identifying key concepts}

\section{Innovation capability}

The capacity to innovate is a key driver in management of innovation (Neely et al. 2001). Innovation capability has been suggested to be a multi-faceted construct. There is no common way of analysis by which to study it, due to the variety of perspectives of innovation management (Perdomo-Ortiz et al., 2006). Thus, the term innovation capability has been defined in several ways. For example, previous studies have classified innovation capability in two entities: technical and managerial aspects of innovation capability (Liao et al., 2007; Tuominen and Hyvönen, 2004). Technological innovation is about capabilities in developing new technology, products or processes. Managerial aspects may for example relate to managerial, market, and marketing aspects. In this paper, a broader conceptualisation of innovation capability is adopted. Thus, innovation capability may relate to new products, processes, services, management, marketing, or work organisation systems. Definitions of innovation capability are presented in Table 1. According to these definitions, innovation capability has at least the following features:

- Innovation capability refers to a potential or ability to produce innovations (e.g. Neely et al, 2001; Lawson and Samson 2001; Laforet 2011)

- Innovation capability is internal capability (e.g. Martínez-Román et al., 2011; Ngo and O'Cass 2009; Akman and Yilmaz, 2008)

- Innovation capability requires continuous improvement (e.g. Olsson et al. 2010; Lawson and Samson 2001; Szeto 2000) 
Saunila, M. (2016). Performance measurement approach for innovation capability in SMEs. International Journal of Productivity and Performance Management, 65(2), 162-176.

- Innovation capability aims to add value (e.g. Hogan et al., 2011; Szeto 2000)

On the basis of earlier definitions, innovation capability is defined in this study as an internal capability aiming to describe the determinants affecting an organisation's ability to achieve innovations continuously and add value for the organisation and its stakeholders.

Table 1. Definitions of innovation capability

\begin{tabular}{|c|c|c|}
\hline Term & Definition & Author(s) \\
\hline Innovation capacity & $\begin{array}{l}\text { continuous improvement of capabilities and resources that an enterprise possesses in order to explore } \\
\text { and exploit opportunities for developing new products to meet market needs }\end{array}$ & Szeto 2000 \\
\hline Capacity to innovate & the potential to generate innovative outputs & Neely et al. 2001 \\
\hline $\begin{array}{l}\text { Innovation } \\
\text { capability }\end{array}$ & $\begin{array}{l}\text { the ability to continuously transform knowledge and ideas into new products, processes and systems } \\
\text { for the benefit of the firm and its stakeholders }\end{array}$ & $\begin{array}{l}\text { Lawson and Samson } \\
2001\end{array}$ \\
\hline $\begin{array}{l}\text { Innovation } \\
\text { capability }\end{array}$ & $\begin{array}{l}\text { an important factor that facilitates an innovative organisational culture, characteristics of internal } \\
\text { promoting activities and capabilities of understanding and responding appropriately to the external } \\
\text { environment }\end{array}$ & Akman and Yilmaz 2008 \\
\hline $\begin{array}{l}\text { Innovation-based } \\
\text { capability }\end{array}$ & $\begin{array}{l}\text { the integrative process of applying the collective knowledge, skills, and resources of the firm to } \\
\text { perform innovation activities pertaining to technical innovations (products and or services, and } \\
\text { production process technology), and non-technical innovations (managerial, market, and marketing) }\end{array}$ & Ngo and O'Cass 2009 \\
\hline $\begin{array}{l}\text { Innovation } \\
\text { capability }\end{array}$ & ability to continuously develop innovations as a response to a changing environment & Olsson et al. 2010 \\
\hline $\begin{array}{l}\text { Innovation } \\
\text { capability }\end{array}$ & $\begin{array}{l}\text { a firm's ability, relative to its competitors, to apply the collective knowledge, skills, and resources to } \\
\text { innovation activities relating to new products, processes, services, or management, marketing or work } \\
\text { organisation systems, in order to create added value for the firm or its stakeholders }\end{array}$ & Hogan et al. 2011 \\
\hline Innovation capacity & refers to availability of resources, collaborative structures, and processes to solve problems & Laforet 2011 \\
\hline
\end{tabular}

\section{Performance}

Laitinen (1998) defines performance as the ability of the measurement object to generate outputs which can be measured by predetermined characteristics relative to predetermined goals. According to Lönnqvist (2004), performance can be defined as the ability of the measurement object to achieve results in relation to goals. Performance can refer to actual results/outputs of certain activities, how an activity is carried out, or an ability to achieve results (Lönnqvist, 2004).

Performance can also be defined through the dimensions that performance can be measured in. These dimensions include for example finances (Hudson et al., 2001), effectiveness (Sink, 1985), efficiency (Sink, 1985), profitability (Sink, 1985), productivity (Sink, 1985; De Toni and Tonchia, 2001), quality (Sink, 1985; Hudson et al., 2001; De Toni and Tonchia, 2001), time (Hudson et al., 2001; De Toni and Tonchia, 2001), flexibility (Hudson et al., 2001; De Toni and Tonchia, 2001), quality of working life/human resources (Sink, 1985; Hudson et al., 2001), customer satisfaction (Hudson et al., 2001), and innovation (Sink, 1985). According to Fitzgerald et al. (1991, in Neely et al., 2000), there are two basic types of performance measure in any organisation, those that are related to results (competitiveness, financial performance), and those that focus on the determinants of the results (quality, flexibility, resource utilisation and innovation). In addition, there are various performance measurement frameworks that are divided into perspectives that organisational performance can be measured in (e.g. Kaplan and Norton, 1996; Neely et al., 2002). The strength of a framework lie in the way how it takes into 
account different areas of performance: financial and non-financial performance, as well as internal and external performance (Neely et al., 2000).

In this paper, performance refers to outputs. Both innovation and innovation capability are defined as predictors of performance. A firm's performance is divided into two main areas: operational performance and financial performance. Financial performance is related to the results (profitability etc.) and operational performance to the determinants of the results (productivity, quality etc.). Financial performance can be measured via cost-based measures, but when measuring operational performance, both cost-based and non-cost measures can be utilised.

\section{Performance measurement}

Neely et al. (2005) define performance measurement as the process of quantifying the efficiency and effectiveness of action. Performance measurement is a process used to determine the status of an attribute or attributes of the measurement objects (Lönnqvist, 2004). Radnor and Barnes (2007) state that performance measurement can also be defined by quantifying the input, output, or level of activity of an event or process. Performance management is action based on performance measurement, which results in improvements in behaviour, motivation and processes. Further, Radnor and Barnes (2007) consider that performance measurement is about efficiency, productivity and utilisation, whereas performance management builds on performance measurement and is concerned with effectiveness and a broader, more holistic, even qualitative view of operations and the organisation. In this study, the definition of performance measurement is based on that of Lönnqvist (2004): Performance measurement is a process of determining the status of the attributes of the measurement objects. Performance management is about utilisation of the information generated through performance measurement.

\subsection{Determinants of innovation capability}

A body of literature has identified aspects that affect an organisation's capability to manage innovation (e.g. Smith et al, 2008; Wan et al, 2005; Tang, 1998, 1999). These aspects are also considered in forming the determinants that overall innovation capability consists of (e.g. Saunila and Ukko, 2013). However, innovation capability may not be a unitary set of attributes, and the attributes do not operate independently of each other but are interrelated (Francis and Bessant, 2005; Smith et al., 2008; Kallio et al., 2012). Different kinds of innovation may require distinctive approaches (Francis and Bessant, 2005), or different types of organisations may utilise different determinants when developing innovation capability (Saunila and Ukko, 2014). Thus, innovation capability varies from firm to firm and is determined by multiple factors (Silva et al., 2012). Innovation capability itself is not a separately identifiable construct. The capability is composed of reinforcing practices and processes within the firm. These processes 
Saunila, M. (2016). Performance measurement approach for innovation capability in SMEs. International Journal of Productivity and Performance Management, 65(2), 162-176.

are a key mechanism for stimulating, measuring and reinforcing innovation (Lawson and Samson, 2001).

As a result of the review of previous literature, innovation capability has been defined to consist of the determinants affecting an organisation's capability to manage innovation. The main determinants of innovation capability utilised in this paper are based on the definition presented by Saunila and Ukko (2013) and further developed by the present author. Innovation capability has been divided into seven determinants and two enabling determinants. A summary of the determinants and their sub-categories is presented in Table 2.

Table 2. Summary of the determinants of innovation capability

\begin{tabular}{|c|c|c|c|}
\hline & & References & Description \\
\hline \multicolumn{4}{|l|}{ Determinants } \\
\hline \multirow{4}{*}{$\begin{array}{l}\text { Leadership } \\
\text { culture }\end{array}$} & Leadership/Management style & Smith et al. 2008 Tang 1998, 1999, Martensen et al. 2008 & \multirow{4}{*}{$\begin{array}{l}\text { The overall atmosphere of the } \\
\text { organisation that supports and motivates } \\
\text { innovation, and also leadership that } \\
\text { facilitates innovation }\end{array}$} \\
\hline & Supervision and control & Martínez-Román et al. 2011 & \\
\hline & Resource management & Lawson and Samson 2001, Smith et al. 2008, Wan et al. 2005 & \\
\hline & Management personalities & Smith et al. 2008 & \\
\hline \multirow{5}{*}{$\begin{array}{l}\text { Work } \\
\text { climate and } \\
\text { wellbeing }\end{array}$} & Innovation culture & Martensen et al. 2008, Neely et al. 2001, Laforet 2011 & \multirow{5}{*}{$\begin{array}{l}\text { Represent the wellbeing of the } \\
\text { employees and further the work climate } \\
\text { for innovation development, including } \\
\text { collaboration and values }\end{array}$} \\
\hline & Communication & Lawson and Samson 2001, Wan et al. 2005, Smith et al. 2008 & \\
\hline & Attitude to innovation & Wan et al. 2005, Smith et al. 2008 & \\
\hline & Collaboration & Smith et al. 2008 & \\
\hline & Shared values & Tang 1998,1999 & \\
\hline \multirow{5}{*}{$\begin{array}{l}\text { Ideation- } \\
\text { and } \\
\text { organising } \\
\text { structures }\end{array}$} & $\begin{array}{l}\text { Organisational structure and } \\
\text { operation processes }\end{array}$ & $\begin{array}{l}\text { Lawson and Samson 2001, Kallio et al. 2012, Tang 1998, } \\
\text { 1999, Neely et al. } 2001\end{array}$ & \multirow{5}{*}{$\begin{array}{l}\text { Related to the structures and systems that } \\
\text { successful innovation requires. This } \\
\text { includes the generation, development and } \\
\text { implementation of innovations, and the } \\
\text { ways how the work tasks of the } \\
\text { organisation are organised }\end{array}$} \\
\hline & Idea generation and management & Lawson and Samson 2001, Smith et al. 2008 & \\
\hline & Rewards & Lawson and Samson 2001, Martínez-Román et al. 2011 & \\
\hline & Level of decentralisation & $\begin{array}{l}\text { Wan et al. 2005, Martínez-Román et al. 2011, Smith et al. } \\
2008\end{array}$ & \\
\hline & Cross-functional communication & Martínez-Román et al. 2011, Tang 1998, 1999 & \\
\hline \multirow[t]{3}{*}{$\begin{array}{l}\text { Know-how } \\
\text { development }\end{array}$} & Professional knowledge and skills & $\begin{array}{l}\text { Romijn and Albaladejo 2002, Tang 1998, 1999, Smith et al. } \\
2008\end{array}$ & \multirow{3}{*}{$\begin{array}{l}\text { Skills and knowledge of the employees } \\
\text { play an important role in innovation } \\
\text { capability. This includes the utilisation of } \\
\text { knowledge as well as the improvement of } \\
\text { employee skills }\end{array}$} \\
\hline & Further learning & Romijn and Albaladejo 2002, Tang 1998, 1999 & \\
\hline & Training, education & Smith et al. 2008 & \\
\hline \multirow{3}{*}{$\begin{array}{l}\text { Exploiting } \\
\text { external } \\
\text { knowledge }\end{array}$} & $\begin{array}{l}\text { Knowledge of external } \\
\text { environment }\end{array}$ & Smith et al. 2008, Neely et al. 2001 & \multirow{3}{*}{$\begin{array}{l}\text { The importance of the proper behavior of } \\
\text { exploiting external networks and } \\
\text { knowledge to the overall organisational } \\
\text { innovation capability }\end{array}$} \\
\hline & Intensity of networking & Romijn and Albaladejo 2002, Kallio et al. 2012 & \\
\hline & $\begin{array}{l}\text { Learning about customers and } \\
\text { competitors }\end{array}$ & Lawson and Samson 2001, Martensen et al. 2008 & \\
\hline \multirow{3}{*}{$\begin{array}{l}\text { Regeneratio } \\
\text { n }\end{array}$} & Organisational learning & Smith et al. 2008 & \multirow{3}{*}{$\begin{array}{l}\text { An organisation's ability to learn from } \\
\text { earlier experience and to use that } \\
\text { experience to create innovations and } \\
\text { develop their operations }\end{array}$} \\
\hline & Attitude to risk & Smith et al. 2008, Wan et al. 2005, Laforet 2011 & \\
\hline & Learning and capacitation & Martínez-Román et al. 2011 & \\
\hline \multirow{4}{*}{$\begin{array}{l}\text { Individual } \\
\text { activity }\end{array}$} & Attitude/willingness to innovate & Wan et al. 2005, Martínez-Román et al. 2011 & \multirow{4}{*}{$\begin{array}{l}\text { Employees' individual innovation } \\
\text { capability and activity is needed to form } \\
\text { the organisation's overall innovation } \\
\text { capability. }\end{array}$} \\
\hline & Creative thinking behavior & Tang 1998, 1999, Kallio et al. 2012 & \\
\hline & Employee motivation & Smith et al. 2008, Tang 1998, 1999, Kallio et al. 2012 & \\
\hline & Empowered employees & Lawson and Samson 2001, Kallio et al. 2012 & \\
\hline \multicolumn{4}{|l|}{ Enablers } \\
\hline \multirow[t]{2}{*}{ Resources } & $\begin{array}{l}\text { Organisational (Financial, } \\
\text { Technology) resources }\end{array}$ & Smith et al. 2008, Tang 1998, 1999, Wan et al. 2005 & \multirow{2}{*}{$\begin{array}{l}\text { Resources that make it possible to } \\
\text { develop organisational capability to } \\
\text { produce innovations }\end{array}$} \\
\hline & People & Laforet 2011, Smith et al. 2008 & \\
\hline $\begin{array}{l}\text { Vision and } \\
\text { strategy }\end{array}$ & $\begin{array}{l}\text { Vision, organisational strategy, } \\
\text { innovation strategy, goals, } \\
\text { mission }\end{array}$ & $\begin{array}{l}\text { Lawson and Samson 2001, } \\
\text { Martensen et al. 2007, Tang 1998, 1999, Smith et al. 2008, } \\
\text { Laforet } 2011\end{array}$ & $\begin{array}{l}\text { Vision and strategy that direct an } \\
\text { organisation's innovation activities and } \\
\text { capability development }\end{array}$ \\
\hline
\end{tabular}


Saunila, M. (2016). Performance measurement approach for innovation capability in SMEs. International Journal of Productivity and Performance Management, 65(2), 162-176.

\section{3}

\section{Uses and impacts of performance measurement}

Companies use performance measurement for various purposes. The reasons for measurement include for example monitoring and controlling (e.g. Simons, 2000; De Toni and Tonchia, 2001; Bitici et al., 2002), decision-making (e.g. Simons, 2000), driving and maximising improvement (e.g. Bitici et al., 2002), achieving alignment with organisational goals and objectives (e.g. Simons, 2000; De Toni and Tonchia, 2001; Bitici et al., 2002), rewarding and motivating (e.g. Simons, 2000; Bitici et al., 2002) and communication (e.g. Simons, 2000). A typical performance measurement helps businesses in setting business goals periodically and then providing feedback to managers on progress towards those goals (Simons, 2000). Thus, evaluation is an important link in the control structure of organisations (Ferreira and Otley, 2009).

When utilising performance measurement, some positive effects can be attained if the measurement has been conducted in a proper way. The impacts of performance measurement have been studied by many researchers. Performance measurement can have positive impacts on leadership and management (Ukko et al., 2007), the ability to exploit existing strategic capabilities, the capacity to identify and develop new strategic capabilities (Graftona et al., 2010), and employees' motivation, learning opportunities, decision -making opportunities, and achievement of goals (Ukko et al., 2008). According to Pavlov and Bourne (2011), the impacts of performance measurement depend on the way it is used. Performance measurement can affect an organisation's routines in three ways. Pavlov and Bourne (2011) call them as the trigger effect of measurement, the guidance effect of measurement, and the intensification effect of measurement. First, when measurement is used in its feedback-generating function, the measures communicate the results of the past execution of the routine and indicate whether its performance is adequate to the demands of the environment. Second, when measurement is used in its feed-forward function, it can affect the direction of the change in organisational processes. Third, measuring performance forces to search for a match between the existing idea and expression of the routine and stimulates the process of adjusting them in order to respond to the new demands of the environment.

Also the impacts of performance measurement systems have been the subject of various studies. The study of Franco-Santos et al. (2007) reveals that business performance measurement systems can have five different kinds of roles. These include the traditional performance measurement/monitoring, strategy management, communication, influence behavior, and learning and improvement. A successfully implemented and used performance measurement system, through cultural change, leads to a more participative and consultative management style. Similarly, the correct use of performance measurement systems can lead to an achievement culture (Bititci et al., 2004; Bititci et al., 2006). Also Hall (2008) has studied the impacts of performance measurement systems on management. The results indicate that comprehensive performance measurement systems influence managers' cognition and 
motivation. The performance measurement system may also have a positive impact on an individual's performance and employee satisfaction (Dumond, 1994; Lawson et al., 2003). A study of de Leeuwa and van den Berg (2011) reveals that performance management practices influence some behavioural factors, which they call understanding, motivation and focus on improvement. "Understanding" is related to understanding shopfloor performance; "motivation" is related to the acceptance of performance measures by operators and motivation to realise performance and active discussion of performance; and "focus on improvement" is related to using performance management to improve within and across organisational departments.

A conceptual framework for developing innovation capability

\section{1}

\section{Development of the framework}

The framework has been built by making a literature review to form an understanding about previous work in the research area and building the theoretical background of the research. As a first step, the key concepts utilised in the paper were defined. A concept is an abstract, general and compact definition of a phenomenon. Precisely defined concepts are essential for scientific research, especially when the measurement of a phenomenon is carried out (Olkkonen, 1994). Second, a basis for the conceptual framework was developed by examining and matching the existing literature of innovation capability and performance measurement. Moore et al. (2009) define a conceptual framework as a set of coherent concepts organised in a manner that helps people understand how and why something takes place. The concepts that constitute a conceptual framework support one another, articulate their respective phenomena, and establish a framework-specific philosophy (Jabareen, 2009). A conceptual framework is not necessarily a tested theory, although it may contain a number of tested theories. It is about connections and elements of knowledge in a general area of inquiry, giving coherence and direction to the study of empirical problems (Moore et al., 2009; Gurevitch et al., 2011). As a summary, the features of conceptual frameworks can be defined as follows (Levering, 2002; Jabareen, 2009):

- A conceptual framework is a construct in which each concept plays an integral role.

- A conceptual framework provides an interpretative approach to social reality.

- Conceptual frameworks provide understanding.

- A conceptual framework provides "soft interpretation of intentions".

- Conceptual frameworks do not enable predicting an outcome.

- Conceptual frameworks can be developed and constructed through a process of qualitative analysis.

- The sources of data consist of many discipline-oriented theories that become empirical data of conceptual framework analysis. 
Finally, an understanding on what is the role of performance measurement in improving innovation capability in SMEs was formed. As a result, a framework for innovation capability improvement in SMEs is presented and key issues that must be addressed are highlighted and discussed below.

\subsection{Description of the framework}

The developed framework is presented in Figure 1. Through the analysis of earlier literature, four propositions were formed. The first proposition is as follows:

Proposition 1. A firm's innovation capability is determined by firm-specific contextual factors and enablers.

The most important development targets of innovation capability depend on firm-specific contextual factors, such as size and industry. There are also enabling factors without which companies will not be able to innovate (Laforet, 2011). These include resources such as financial resources and workforce. Also vision and strategy that support innovation capability and its development may act either as enablers or obstacles of innovation capability. These things are prerequisites that have to be taken into account when developing innovation capability, although they are difficult to change. The second proposition is:

Proposition 2. A firm's innovation capability consists of seven determinants that overlap and influence each other iteratively.

Innovation capability may not be a homogenous collection of factors, but different kinds of innovations (Francis and Bessant, 2005) and different kinds of firms (Silva et al., 2012; Kallio et al., 2012) may require utilising and developing different determinants. One determinant can affect a range of other determinants. As found in the literature review, these determinants are leadership culture, work climate and wellbeing, ideation- and organising structures, knowhow development, exploiting external knowledge, regeneration, and individual activity. A firm can develop and affect the determinants by its own behaviour. Although the determinants do not follow each other in a certain order, it is probable that certain determinants should be developed before others. Smith et al. (2008) present that organisational culture is a factor that impacts all others and is also impacted upon by changes in the other factors. In the present framework, the work climate and wellbeing and leadership culture are regarded the ones that should be improved first. After that, developing the other determinants is more likely to succeed. The third proposition is as follows:

Proposition 3. Innovation capability can be developed through a proper use of performance measurement. 
Previous research has presented many positive impacts of performance measurement. As pointed out by Neely et al. (2000), measurement must not be seen as obtrusive and contradictory within innovation. When measurement has been conducted in a proper way, it can boost innovation capability development. Especially in the context of innovation, the measures should be dynamic and changeable and continually reviewed and developed during the transitional process of developing the innovation capability (Neely et al., 2000; McAdam and Keogh, 2004). It is also emphasised that measuring innovation must be given more strategic and operational importance and a wide range of measures should be adopted, reflecting the diversity within innovation (McAdam and Keogh, 2004). This way the measures can be used as a tool of management in the everyday context when aiming to guide and direct innovation capability and related activities towards the firm strategy. The fourth proposition deals with enhancing the performance of SMEs through developing innovation capability.

Proposition 4. Facilitating innovation capability through performance measurement enhances a firm's performance.

In order to increase the competitiveness of SMEs through innovativeness, attention should be paid to innovation measurement (McAdam and Keogh, 2004). The measurement should be systematic to enable the development of innovation capability and to be able to make proper decisions based on the measurement information. Neely (2005) has stated that organisational focus should be redirected from performance measurement to performance management. Similarly, as regards innovation capability measurement, the focus should be on evaluating and reacting to the changes in innovation measurement information in a way that performance improvement is possible. The problem of current innovation measurement is the lack of measurement where innovation-focused measures are aligned with each other and with the firm strategy (Adams et al. 2006). Measurement is needed along multiple levels and phases. Thus, measurement should be realised in each phase of the process of turning the capability in to a firm asset. The innovation capability measures should be complementary to each other. Innovation capability, as well as its enablers should have their own measures that are linked to each other. Because innovation capability is expected to affect operational performance and in the long run also financial performance, the innovation capability measures and performance measures need to be linked to each other as well. This means formulating causal linkages between the innovation capability measures and SME performance measures. These causal linkages can help SMEs to follow how the development of innovation capability assists their attempts to achieve performance goals. 


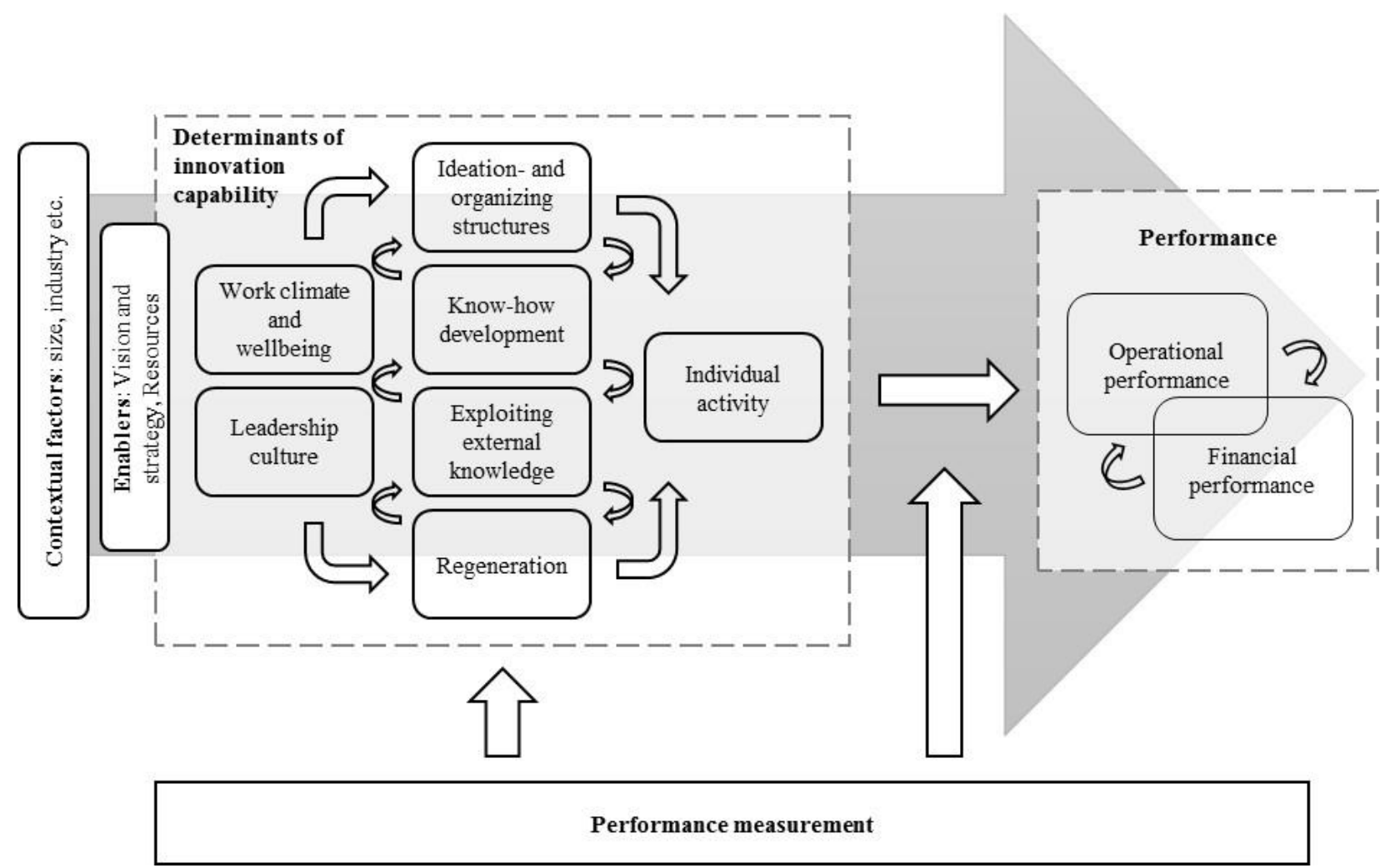

Figure 1. Framework for improving innovation capability in SMEs

\section{Conclusions}

The purpose of the paper was to present a framework for improving innovation capability through performance measurement in SMEs. First, the paper contributes to the current understanding by providing a holistic definition of innovation capability, when a majority of existing studies focus on limited aspects of innovation capability only. Second, the study identifies the uses and impacts of performance measurement, especially when developing innovation capability. Third, this study provides four propositions to establish a framework that can assist SMEs in their attempts to develop their innovation capability through measurement, whereas there is a lack of attempts in the current literature to provide frameworks for improving innovation capability through performance measurement, at least to SMEs.

The categorisation presented in this paper provides a good starting point for defining the intangible aspects of organisational innovation capability. Using the results of this study, practitioners can improve their innovation capability through performance measurement by taking better account of various aspects. The framework has been constructed especially to SMEs. However, it contains elements that are applicable also to larger companies. However, SMEs have characteristics that differentiate them from larger companies and thus certain elements are highlighted. The presented framework can assist future research by providing definitions and connections between concepts related to innovation capability and performance measurement. The presented framework is based on theoretical investigation, and thus 
empirical investigation is needed to evaluate the possible empirical applications of the framework. Further studies should focus on validating the proposed framework in terms of suitability, usefulness and acceptability. Testing the framework in an empirical setting would provide useful information to practitioners when applying the framework. The present study does not provide measures for developing innovation capability. Further research should concentrate on developing measures that assist in this task. Another subject for future research is an empirical examination of the relationships between the determinants of innovation capability. This work would also assist the measurement of the determinants.

\section{References}

Adams, R., Bessant, J. and Phelps, R. (2006), "Innovation management measurement: A review”, International Journal of Management Reviews, Vol. 8 No. 1, pp. 21-47.

Akman, G. and Yilmaz, C. (2008), "Innovative capability, innovation strategy and market orientation: an empirical analysis in Turkish software industry", International Journal of Innovation Management, Vol. 12 No. 1, pp. 69-111.

Bititci, U., Carrie, A. and Turner, T. (2002), Integrated performance measurement systems: Structure and dynamics. In Neely, A. (Ed.) Business Performance Measurement: Theory and Practice. Cambridge University Press.

Bititci, U., Garengo, P., Dörfler, V. and Nudurupati, S. (2012), "Performance Measurement: Challenges for Tomorrow”, International Journal of Management Reviews, Vol. 14 No. 3, pp. 305-327.

Bititci, U.S., Mendibil, K., Nudurupati, S., Garengo, P. and Turner, T. (2006), "Dynamics of performance measurement and organisational culture", International Journal of Operations \& Production Management, Vol. 26 Iss. 12, pp. 1325-1350.

Bititci, U.S., Mendibil, K., Nudurupati, S., Turner, T. and Garengo, P. (2004), “The interplay between performance measurement, organizational culture and management styles", Measuring Business Excellence, Vol. 8 Iss. 3, pp. 28-41.

Bourne, M., Kennerley, M. and Franco-Santos, M. (2005), "Managing through measures: a study of impact on performance", Journal of Manufacturing Technology Management, Vol. 16 No. 4, pp. 373-395.

Çakar, N.D. and Ertürk, A. (2010), "Comparing Innovation Capability of Small and MediumSized Enterprises: Examining the Effects of Organizational Culture and Empowerment", Journal of Small Business Management, Vol. 48 No. 3, pp. 325-359. 
De Leeuwa, S. and van den Berg. J.P. (2011), "Improving operational performance by influencing shopfloor behavior via performance management practices", Journal of Operations Management, Vol. 29 Iss. 3, pp. 224-235.

Delgado-Verde, M., Martín-de Castro, G. and Navas-López, J.E. (2011), "Organizational knowledge assets and innovation capability: Evidence from Spanish manufacturing firms", Journal of Intellectual Capital, Vol. 12 Iss. 1, pp. 5-19

De Toni, A. and Tonchia, S. (2001), "Performance measurement systems - Models, characteristics and measures", International Journal of Operations \& Production Management, Vol. 21 No. 1/2, pp. 46-70.

Dumond, E.J. (1994), "Making best use of performance measures and information", International Journal of Operations and Production Management, Vol. 14 No. 9, pp. 16-31.

Ferreira A. and Otley, D. (2009), "The design and use of performance management systems: An extended framework for analysis", Management Accounting Research, Vol. 20 No. 4, pp. 263-282.

Forsman, H. (2011), "Innovation capacity and innovation development in small enterprises. A comparison between the manufacturing and service sectors", Research Policy, Vol. 40 Iss. 5, pp. 739-750.

Francis, D. and Bessant, J. (2005), "Targeting innovation and implications for capability development”, Technovation, Vol. 25 Iss. 3, pp. 171-183.

Franco, M. and Bourne, M. (2003), "Factors that play a role in "managing through measures" ", Management Decision, Vol. 41 No. 8, pp. 698-710.

Franco-Santos, M., Kennerley, M., Micheli, P., Martinez, V., Mason, S., Marr, B., Gray, D. and Neely, A. (2007), "Towards a definition of a business performance measurement system", International Journal of Operations \& Production Management, Vol. 27 Iss. 8, pp. 784-801.

Graftona, J., Lillisa, A.M. and Widener, S.K. (2010), "The role of performance measurement and evaluation in building organizational capabilities and performance", Accounting, Organizations and Society, Vol. 35 Iss. 7, pp. 689-706.

Gurevitch, J., Fox, G.A., Wardle, G.M., Inderjit and Taub, D. (2011), "Emergent insights from the synthesis of conceptual frameworks for biological invasions", Ecology Letters, Vol. 14 Iss. 4, pp. 407-418. 
Hall, M. (2008), "The effect of comprehensive performance measurement systems on role clarity, psychological empowerment and managerial performance", Accounting, Organizations and Society, Vol. 33 Iss. 2-3, pp. 141-163.

Hausman, A. (2005), "Innovativeness among small businesses: Theory and propositions for future research”, Industrial Marketing Management, Vol. 34 No. 8, pp. 773-782.

Hogan, S.J., Soutar, G.N., McColl-Kennedy, J.R. and Sweeney, J.C. (2011), "Reconceptualizing professional service firm innovation capability: Scale development", Industrial Marketing Management, Vol. 40 Iss. 8, pp. 1264-1273.

Hudson, M., Smart, A. and Bourne, M. (2001), "Theory and practice in SME performance measurement systems", International Journal of Operations \& Production Management, Vol. 21 No. 8, pp. 1096-1115.

Jabareen, Y.R. (2009), "Building a Conceptual Framework: Philosophy, Definitions, and Procedure", International Journal of Qualitative Methods, Vol. 8 No. 4, pp. 49-62.

Kallio, A., Kujansivu, P. and Parjanen, S. (2012), "Locating the Weak Points of Innovation Capability before Launching a Development Project", Interdisciplinary Journal of Information, Knowledge and Management, Vol. 7, pp. 21-38.

Kaplan, R.S. and Norton, D.P. (1996), The Balanced Scorecard, Translating Strategy into Action, Harvard Business School Press, Boston, Massachusetts.

Laforet, S. (2011), "A framework of organisational innovation and outcomes in SMEs", International Journal of Entrepreneurial Behaviour \& Research, Vol. 17 Iss. 4, pp. 380-408

Laitinen, E. (1998), Yritystoiminnan uudet mittarit, Kauppakaari oy, Helsinki.

Laitinen, E. (2003), Yritystoiminnan uudet mittarit, 3rd ed., Talentum, Helsinki.

Lawson, B., Samson, D. (2001), "Developing innovation capability in organisations: a dynamic capabilities approach", International Journal of Innovation Management, Vol. 5 No. 3, pp. $377-$ 400 .

Lawson, R., Stratton, W. and Hatch, T. (2003), "The benefits of a scorecard system", CMA Management, Jun/Jul, pp. 24-26. 
Levering, B. (2002), "Concept analysis as empirical method", International Journal of Qualitative Methods, Vol. 1 No. 1, pp. 35-48.

Liao, S-H., Fei, W-C. and Chen, C-C. (2007), "Knowledge sharing, absorptive capacity, and innovation capability: an empirical study of Taiwan's knowledge-intensive industries”, Journal of Information Science, Vol. 33 No. 3, pp. 340-359.

Lönnqvist, A. (2004), Measurement of Intangible Success Factors: Case Studies on the Design, Implementation and Use of Measures, Dissertation, Tampere University of Technology.

Martensen, A., Dahlgaard, J.J., Park-Dahlgaard, S.M., Grønholdt, L. (2007), "Measuring and diagnosing innovation excellence - simple contra advanced approaches: a Danish study", Measuring Business Excellence, Vol. 11 No. 4, pp. 51-65.

Martínez-Román, J.A., Gamero, J. and Tamayo, J.A. (2011), “Analysis of innovation in SMEs using an innovative capability-based non-linear model: A study in the province of Seville (Spain)", Technovation, Vol. 31 Iss. 9, pp. 459-475.

McAdam, R. and Keogh, W. (2004), "Transitioning Towards Creativity and Innovation Measurement in SMEs", Creativity and Innovation Management, Vol. 13 No. 2, pp. 126-139.

Moore, D.E., Green, J.S. and Gallis, H.A. (2009), “Achieving Desired Results and Improved Outcomes: Integrating Planning and Assessment Throughout Learning Activities”, Journal of Continuing Education in the Health Professions, Vol. 29 No. 1, pp. 1-15.

Neely, A. (2005), "The evolution of performance measurement research: developments in the last decade and a research agenda for the next", International Journal of Operations \& Production Management, Vol. 25 No. 12, pp. 1264-1277.

Neely, A., Filippini, R., Forza, C., Vinelli, A., Hii, J. (2001), “A framework for analysing business performance, firm innovation and related contextual factors: perceptions of managers and policy makers in two European regions", Integrated Manufacturing Systems, Vol. 12 No. 2, pp. 114-124.

Neely, A., Gregory, M. and Platts, K. (2005), "Performance measurement system design: A literature review and research agenda", International Journal of Operations \& Production Management, Vol. 25 Iss. 12, pp. 1228-1263.

Neely, A., Mills, J., Platts, K., Richards, H., Gregory, M., Bourne, M. and Kennerley, M. (2000), "Performance measurement system design: developing and testing a process-based 
Saunila, M. (2016). Performance measurement approach for innovation capability in SMEs. International Journal of Productivity and Performance Management, 65(2), 162-176.

approach”, International Journal of Operations \& Production Management, Vol. 20 No. 10, pp. $1119-1145$.

Neely, A., Adams, C. and Kennerley, M. (2002), The Performance Prism, The Scorecard for Measuring and Managing Business Success, Prentice Hall.

Ngo, L.V. and O'Cass, A. (2009), “Creating value offerings via operant resource-based capabilities", Industrial Marketing Management, Vol. 38 Iss. 1, pp. 45-59

Olkkonen, T, (1994), Johdatus teollisuustalouden tutkimustyöhön, 2nd edition, Report No. 152, Helsinki University of Technology, Otaniemi.

Olsson, A., Wadell, C., Odenrick, P. and Bergendahl, M.N. (2010), “An action learning method for increased innovation capability in organizations", Action Learning: Research \& Practice, Vol. 7 Iss. 2, pp. 167-179.

Pavlov, A. and Bourne, M. (2011), "Explaining the effects of performance measurement on performance: An organizational routines perspective", International Journal of Operations \& Production Management, Vol. 31 Iss. 1, pp. 101-122.

Perdomo-Ortiz, J., González-Benitoa, J. and Galende, J. (2006), “Total quality management as a forerunner of business innovation capability”, Technovation, Vol. 26 Iss. 10, pp. 1170-1185.

Radnor, Z.J. and Barnes, D. (2007), "Historical analysis of performance measurement and management in operations management", International Journal of Productivity and Performance Management, Vol. 56 No. 5, pp. 384-396.

Romijn, H., Albaladejo, M. (2002), "Determinants of innovation capability in small electronics and software firms in southeast England”, Research Policy, Vol. 31 Iss. 7, pp. 1053-1067.

Saunila, M., Ukko, J. and Rantanen, H. (2014) Does innovation capability really matter for the profitability of SMEs?, Knowledge and Process Management, 21 (2): 134-142.

Saunila, M. and Ukko, J. (2014) Intangible aspects of innovation capability in SMEs: Impacts of size and industry, Journal of Engineering and Technology Management, 33: 32-46.

Saunila, M. and Ukko, J. (2013) Facilitating innovation capability through performance measurement: A study of Finnish SMEs, Management Research Review, 36 (10): 991-1010. 
Saunila, M., Ukko, J. and Rantanen, H. (2012), Innovation capability and its measurement in Finnish SMEs, In Melkas, H. and Harmaakorpi, V. (Eds.) Practice-based Innovation: Insights, Applications and Policy Implications. Springer.

Silva, M.J.M., Simões, J., Moreira, J. and Sousa, G. (2012), “Investment and Expenditure on Innovation Activities and Innovative Capability: Empirical Evidence from Portuguese Services Firms and KIBS”, International Business Research, Vol. 5 No. 2, pp. 114-122.

Simons, R. (2000), Performance Measurement \& Control Systems for Implementing Strategy. Upper Saddle River: Prentice Hall.

Sink, D. S. (1985), Productivity management: Planning, Measurement and Evaluation, Control and Improvement, John Wiley \& Sons Inc, New York.

Smith, M., Busi, M., Ball, P., Van der meer, R. (2008), “Factors influencing an organisation's ability to manage innovation: a structured literature review and conceptual model", International Journal of Innovation Management, Vol. 12 No. 4, pp. 655-676.

Szeto, E. (2000), "Innovation capacity: working towards a mechanism for improving innovation within an inter-organizational network", The TQM Magazine, Vol. 12 No. 2, pp. 149-158.

Tang, H.K. (1999), “An inventory of organizational innovativeness", Technovation, Vol. 19 Iss. 1, pp. 41-51.

Tang, H.K. (1998), “An integrative model of innovation in organizations”, Technovation, Vol. 18 No. 5, pp. 297-309.

Tuominen, M. and Hyvönen, S. (2004), "Organizational Innovation Capability: A Driver for Competitive Superiority in Marketing Channels", The International Review of Retail, Distribution and Consumer Research, Vol. 14 No. 3, pp. 277-293.

Ukko, J., Tenhunen, J. and Rantanen, H. (2008), "The impacts of performance measurement on the quality of working life", International Journal Business Performance Management, Vol. 10 No. 1, pp. 86-98.

Ukko, J., Tenhunen, J. and Rantanen, H. (2007), "Performance measurement impacts on management and leadership: Perspectives of management and employees", International Journal of Production Economics, Vol. 110 Iss. 1-2, pp. 39-51. 
Saunila, M. (2016). Performance measurement approach for innovation capability in SMEs. International Journal of Productivity and Performance Management, 65(2), 162-176.

Wan, D., Ong, C.H., Lee, F. (2005), "Determinants of firm innovation in Singapore", Technovation, Vol. 25 No. 3, pp. 261-268. 